\title{
Late-season Surface Water Induces Skin Spot in Apple
}

\author{
Andreas Winkler, Eckhard Grimm, and Moritz Knoche ${ }^{1}$ \\ Institute for Horticultural Production Systems, Leibniz-University Hannover, \\ Herrenhäuser Straße 2, 30419 Hannover, Germany
}

\section{Julian Lindstaedt and Dirk Köpcke \\ Fruit Research Center Jork, Chamber of Agriculture Lower Saxony, Moorende 53, 21635 Jork, Germany}

Additional index words. cuticular membrane, fracture, Malus, microcracks, periderm, strain

\begin{abstract}
Skin spot is a commercially important disorder of the fruit skin of 'Elstar' apples (Malus $\times$ domestica Borkh.). The disorder is characterized by patches of small brownish dots ("skin spots") that usually appear on the skin after fruit are removed from storage. Water-induced cuticular microcracks are implicated in the etiology of skin spot. The objectives of our study were 1) to establish the effect of surface wetness on the severity of skin spot; and 2) to identify possible relationships between meteorological records of rainfall over a number of seasons and the severity of skin spot in those seasons. Surface wetness treatments were imposed on fruit using overhead sprinklers installed above trees grown under a plastic rain shelter. During early fruit development [14 to 44 days after full bloom (DAFB)], surface wetness did not affect the severity of skin spot. However, during the later part of the growing season (greater than 44 DAFB), increased surface wetness increased the incidence and severity of skin spot and also the severity of cuticular microcracking. Most skin spots and microcracks were already present at harvest before storage, but skin spots and microcracking did increase slightly during subsequent controlled atmosphere (CA) storage. Over a 9-year period, the severity of skin spot in 'Elstar' apples grown and stored locally under standard orchard and storage conditions was positively correlated to the number of rainy days. This correlation was greater for the period between 1 Aug. to harvest than for periods 1 June to harvest or 1 July to harvest. Fruit treated with 1-methylcyclopropene (1-MCP) were more susceptible to skin spot than untreated control fruit. Calculating regression equations for the relationship between the severity of skin spot and the number of rainy days (period 1 Aug. and harvest) revealed that the (commercially important) threshold score for skin spot of 2 is predicted to occur after 44 rainy days for control fruit and after 34 rainy days for 1-MCP-treated fruit. Our data demonstrate that skin spot arises from cuticular microcracks, which in turn result from numerous exposures to surface wetness (rain, dew), especially those occurring during later stages of fruit development.
\end{abstract}

Skin appearance is an important quality characteristic in almost all fruit crops including apples. Compromised skin appearance usually results in reduced market value. Russeting is a common and familiar example of a surface disorder of some apple cultivars. Skin spot is less well known but an economically important apple disorder in 'Elstar' and occasionally in 'Golden Delicious' (Grimm et al., 2012). The skin spot disorder is usually thought to appear after removal from CA storage (Hennecke et al., 2008; Veltman et al., 2003). Anecdotal reports suggest that fruit are particularly susceptible to skin spot

Received for publication 6 June 2014. Accepted for publication 7 Aug. 2014.

This research was funded by a grant from the Niedersächsisches Ministerium für Wissenschaft und Kultur (grant No. 76251-17-4/09/ZN2543). We thank Friederike Schroeder and Simon Sitzenstock for technical support and Drs. Sandy Lang and Bishnu P. Khanal for helpful comments on an earlier version of this manuscript.

${ }^{1}$ To whom reprint requests should be addressed; e-mail moritz.knoche@obst.uni-hannover.de. if they are poorly colored, from dense canopies, grown in wet years, or harvested late (Köpcke et al., 2002).

Recent investigations have established that skin spot comprises patches of small, brownish spots arranged in a matrix and caused by the death of individual epidermal and hypodermal cells underlying microcracks in the cuticle (Grimm et al., 2012). The protoplasts appear brownish and coagulated. An individual spot is "sealed off" from the surrounding living tissue by lignin impregnation in the cell walls. Based on these observations, we hypothesize that the skin spot disorder is preceded by the formation of microcracks in the cuticle that result in the desiccation and death of the underlying cells. After a cell's death, the loss of membrane integrity results in the oxidation of phenols and consequent browning, thus creating a small, brown "dot." A grouping of these dots creates a skin spot. According to our hypothesis, cuticular microcracking is a prerequisite for the skin spot disorder. Interestingly, surface moisture induces microcracks in the cuticles of many fruit crop species, including apples
(Knoche et al., 2011; Knoche and Grimm, 2008).

The objectives here were to identify the causal-chain relationship among fruit surface water applied by overhead sprinklers, the formation of microcracks in the cuticle, and the severity of skin spot in 'Elstar' apples grown under rain shelters. In addition, we analyzed weather records for the 2005-13 growing seasons to look for potential correlative relationships between the occurrence of rain and the severity of the skin spot disorder.

\section{Materials and Methods}

'Elstar' apples (Malus $\times$ domestica Borkh.) were grown with and without rain shelter in an experimental orchard of the Esteburg Research Station at Jork (long. 53 $50^{\prime} \mathrm{N}$, lat. $\left.9^{\circ} 73^{\prime} \mathrm{E}\right)$, Germany. All fruit were from trees grafted on 'M.9' rootstocks and cultivated according to current European regulations for integrated fruit production.

Irrigation experiments using rain shelters in 2012 and 2013. Rain shelters (height $3.8 \mathrm{~m}$, width $4 \mathrm{~m}$ ) were constructed over single rows of trees in the experimental orchard. A $310-\mu \mathrm{m}$ polyethylene film (Protector; Brändlin Systems, Efringen-Kirchen, Germany) was used as a protective cover. The width of the shelter was such that all fruit from trees under the cover were protected from rainfall. An overhead sprinkler (SuperNet SRD 20; Netafim, Tel Aviv, Israel) was installed above the crown of each tree to be wetted. Sprinklers were controlled by a Galcon 62562 DC-6S (Galcon, Kfar Blum, Israel) computer. Experiments were carried out in both the 2012 and the 2013 growing seasons. In the 2012 experiment, the orchard was covered from 26 June to 24 Sept. (equivalent to 51 to 141 DAFB) at the end of which period the fruit were commercially mature. Two treatments were imposed. Fruit were maintained in a wet condition between 0800 and 2000 HR by overhead sprinkling (every $20 \mathrm{~min}$ for 3 to $5 \mathrm{~min}$ ) from 30 Aug. to 24 Sept., whereas unwetted fruit from sheltered trees served as controls. In 2013, the orchard was covered with the rain shelter on 24 May (4 DAFB) until harvest on 30 Sept. (134 DAFB). Five different wetting treatments were imposed. Fruit were maintained wet between 1) 14 and 44 DAFB; 2) 45 and 78 DAFB; 3) 78 and 108 DAFB; and 4) 100 and 133 DAFB. Fruit from sheltered trees without overhead sprinklers remained dry during these periods and served as controls. In both years, treatments comprised three to four replicates with five (minimum) to 18 trees per replicate. Fruit were harvested at commercial maturity and selected for uniformity such that a maximum of $30 \%$ of the surface area was colored. Subsequently, fruit were stored under CA conditions: in 2012 for $141 \mathrm{~d}$ at $1.6 \pm 0.1{ }^{\circ} \mathrm{C}, 0.5 \% \pm 0.1 \% \mathrm{CO}_{2}, 1.6 \% \pm$ $0.1 \% \mathrm{O}_{2}$; in 2013 for $131 \mathrm{~d}$ at $2.3 \pm 0.0{ }^{\circ} \mathrm{C}, 0.1 \%$ $\pm 0.0 \% \mathrm{CO}_{2}, 1.8 \% \pm 0.0 \% \mathrm{O}_{2}$ ) followed by $14 \mathrm{~d}$ of cool storage $\left(1.5\right.$ to $2.5^{\circ} \mathrm{C}$ ).

Analyses 2012. After harvest, and once again after storage, the severities of skin spot and 
of microcracking were assessed. The severity of skin spot was quantified using a discrete 5-point scale between 0 and 4 , where $0=$ no skin spot, $1=$ less than $1 \mathrm{~cm}^{2}$ of skin was affected by skin spot, 2 = between 1 and 2 $\mathrm{cm}^{2}$ was affected, $3=$ between $2 \mathrm{~cm}^{2}$ and half of the total area was affected, and $4=$ an area greater than half the total was affected (Hennecke et al., 2008). These discrete scores were averaged between replicates to create a semicontinuous score between 0 and 4 . On this scale, the upper threshold for commercially acceptability was $\approx 2$.

The severity of microcracking was quantified using the procedure described by Grimm et al. (2012). Fruit were infiltrated with an aqueous solution of $0.1 \%(\mathrm{w} / \mathrm{v})$ acridine orange buffered in $50 \mathrm{~mm}$ citric acid at $\mathrm{pH} 4.0$ using a mild vacuum $(51.3 \mathrm{kPa})$ for $10 \mathrm{~min}$ and subsequently rinsed and blotted. One to four epidermal segments $(\mathrm{ES} ; \approx 3.5 \times$ $2.5 \mathrm{~cm}$ ) were excised from non-blushed and non-russeted regions of upper and lower hemispheres close to the equatorial plane of the fruit using a razor blade. The ES were transferred to the stage of a fluorescence microscope (MZ10F, filters GFP-plus 480 to $440 \mathrm{~nm}$ excitation, $510 \mathrm{~nm}$ emission or greater; Leica Mikrosysteme GmbH, Wetzlar, Germany) and photographed (DP71; Olympus Europa, Hamburg, Germany). The area infiltrated by the fluorescent dye was quantified using image analysis $\left(\right.$ cell $^{\wedge} \mathrm{p}$; Olympus Europa).

Analyses 2013. Skin spot severity was quantified using the same procedure as in 2012. The incidence of skin spots as indexed by the percentage of fruit having a skin spot score greater than 0 was calculated. In addition, the area affected by russeting was determined by image analysis. Fruit were cut longitudinally into eight segments, peeled, and the peel flattened on a glass plate. To enhance contrast, the area of the peel affected by russeting was painted black using acrylic paint. The glass plate was then photographed (EOS 550D, lens EF-S 18-55 mm; Canon, Tokyo, Japan) and the area affected by russeting quantified by image analysis $\left(\mathrm{cell}^{\wedge} \mathrm{p}\right.$; Olympus Europa).

Relationship between the severity of skin spot and rainfall in the 2005-13 seasons. To establish relationships between the severity of skin spot and naturally occurring rain events, daily amounts of rain $(\mathrm{mm})$ and the number of days with rain (rainy days) between full bloom and harvest were obtained from a local weather station and correlated with the average severity of skin spot under standard conditions. The average severity of skin spot was monitored in 'Elstar' apples cultivated under standard conditions in the years 2005-13. Fruits were held in CA storage at 1.5 to $2.5^{\circ} \mathrm{C}$, relative humidity greater than $92 \%, \mathrm{CO}_{2}$ and $\mathrm{O}_{2}$ concentrations of 2.6 and $2.0 \%$, respectively, with and without a $24-\mathrm{h}$ pre-storage exposure to $630 \mathrm{ppm}$ 1-MCP (Rohm and Haas, Philadelphia, PA). The severity of skin spot was assessed using the rating scheme described previously.
Data analyses. Data were subjected to correlation (Proc Corr) and regression analyses (Proc Reg) using SAS (Version 9.1.3; SAS Institute, Cary, NC). The results in Tables 1 and 2 are presented as means and SEMS.

\section{Results}

Increasing fruit surface wetness by overhead sprinkling increased both the severity of skin spot and the severity of cuticular microcracking (Table 1). Most skin spots and microcracks were already present by harvest time and before storage. However, the severities of both increased significantly during storage (Table 1).

There was essentially no skin spot or russeting when the fruit surfaces were kept dry. Also, surface wetness between 14 and 44 DAFB had no effect on the severity of skin spot compared with dry, control fruit but markedly increased the surface area percentage of the skin that was russeted (Table 2). When fruit surfaces were kept wet during the later stages of development (greater than 44

Table 1. Effect of fruit surface wetness on the severities of skin spot and of cuticular microcracks in 'Elstar' apple fruit pre- and post-storage in the 2012 growing season. ${ }^{2}$

\begin{tabular}{|c|c|c|c|}
\hline & & Skin spot & Microcracks \\
\hline Time & Treatment & $\overline{[\text { mean } \pm \text { SE (score) }]}$ & {$[$ mean $\pm \mathrm{SE}(\%$ area $)]$} \\
\hline \multirow[t]{2}{*}{ Pre-storage } & Control & $0.2 \pm 0.0$ & $0.2 \pm 0.0$ \\
\hline & Wet & $1.5 \pm 0.1$ & $4.6 \pm 0.7$ \\
\hline \multirow[t]{2}{*}{ Post-storage } & Control & $0.9 \pm 0.0$ & $0.3 \pm 0.0$ \\
\hline & Wet & $2.1 \pm 0.1$ & $7.2 \pm 1.0$ \\
\hline
\end{tabular}

${ }^{2}$ Fruit surface wetness was maintained by overhead sprinklers installed above trees grown under a rain shelter [deployed between 51 and $141 \mathrm{~d}$ after full bloom (DAFB)]. Sprinklers were operated for $24 \mathrm{~d}(116$ to 140 DAFB) before harvest ("wet"). Fruit from sheltered trees without sprinklers remained dry during this period and served as controls ("control"). The severity of skin spot was quantified at harvest (prestorage, $141 \mathrm{DAFB})$ and again after $141 \mathrm{~d}$ of storage in a controlled atmosphere $\left(1.6 \pm 0.1{ }^{\circ} \mathrm{C}, 0.5 \pm 0.1 \%\right.$ $\mathrm{CO}_{2}, 1.6 \pm 0.1 \% \mathrm{O}_{2}$ ) followed by $14 \mathrm{~d}$ of cool storage. Skin spot severity was scored on a 0 to 4 scale (where $0=$ no skin spot, through $4=$ more than half the surface affected by skin spot; see text for further details). The cuticular microcracks were quantified by measuring the area (\%) of fruit surface infiltrated with an aqueous solution of the fluorescent tracer acridine orange. The number of individual fruit replicates ranged from 106 to 347 fruit per treatment.

Table 2. Effect of surface wetness on the severity and incidence of skin spot and on russeting in 'Elstar' apple in the 2013 growing season. ${ }^{z}$

\begin{tabular}{|c|c|c|c|c|c|}
\hline \multirow[b]{3}{*}{ Time } & \multirow[b]{3}{*}{ Treatment } & \multirow{3}{*}{$\frac{\text { Wetness period }}{\text { (DAFB) }}$} & \multicolumn{2}{|c|}{ Skin spot } & \multirow{2}{*}{ Russeting } \\
\hline & & & \multirow{2}{*}{$\begin{array}{c}\text { Severity } \\
{[\text { mean } \pm \text { SE (score) }]}\end{array}$} & \multirow{2}{*}{$\begin{array}{c}\text { Incidence } \\
{[\text { mean }(\%)]}\end{array}$} & \\
\hline & & & & & {$[$ mean $\pm \mathrm{SE}(\operatorname{area} \%)]$} \\
\hline \multirow[t]{5}{*}{ Pre-storage } & Control & - & $0.0 \pm 0.0$ & 0 & $1.5 \pm 0.3$ \\
\hline & Wet & 14 to 44 & $0.0 \pm 0.0$ & 3 & $8.7 \pm 1.6$ \\
\hline & Wet & 45 to 78 & $1.4 \pm 0.2$ & 80 & $2.4 \pm 0.4$ \\
\hline & Wet & 78 to 108 & $1.5 \pm 0.2$ & 85 & $2.7 \pm 0.5$ \\
\hline & Wet & 100 to 133 & $1.1 \pm 0.1$ & 90 & $2.3 \pm 0.3$ \\
\hline \multirow[t]{5}{*}{ Post-storage } & Control & - & $0.4 \pm 0.1$ & 35 & $0.6 \pm 0.1$ \\
\hline & Wet & 14 to 44 & $0.4 \pm 0.1$ & 38 & $7.1 \pm 1.0$ \\
\hline & Wet & 45 to 78 & $1.8 \pm 0.2$ & 93 & $2.6 \pm 0.4$ \\
\hline & Wet & 78 to 108 & $2.1 \pm 0.2$ & 98 & $2.2 \pm 0.3$ \\
\hline & Wet & 100 to 133 & $1.8 \pm 0.2$ & 90 & $1.4 \pm 0.3$ \\
\hline
\end{tabular}

${ }^{\mathrm{z}}$ Fruit surface wetness was maintained by overhead sprinklers installed above trees grown under a plastic rain shelter [deployed between 5 and $134 \mathrm{~d}$ after full bloom (DAFB)]. Four different wetness periods were imposed. Fruit borne on sheltered trees without overhead sprinklers remained dry throughout this period and served as controls ("control"). The severity of skin spot was quantified at harvest (pre-storage, at 134 DAFB) and again after $131 \mathrm{~d}$ of controlled atmosphere $\left(2.3 \pm 0.0{ }^{\circ} \mathrm{C}, 0.1 \pm 0.0 \% \mathrm{CO}_{2}, 1.8 \pm 0.0 \% \mathrm{O}_{2}\right)$ followed by $14 \mathrm{~d}$ of cool storage. Skin spot severity was scored on a 0 to 4 scale (where $0=$ no skin spot, through $4=$ more than half the surface affected by skin spot; see text for further details). The incidence of skin spots was determined as the percentage of fruit having a skin spot score greater than 0 . The severity of russeting was quantified as the fraction (\%) of the fruit surface area affected. The number of fruit replicates ranged above a minimum of 40 fruit per treatment. 
Table 3. Coefficients of correlation between the severity of skin spot in 'Elstar' apple over nine growing seasons (2005-13) and cumulative rainfall amount or number of rainy days in those seasons. ${ }^{\mathrm{z}}$

\begin{tabular}{|c|c|c|c|c|}
\hline \multirow[b]{3}{*}{ Time period } & \multicolumn{4}{|c|}{ Pearson coefficients of correlation $(r)$} \\
\hline & \multicolumn{2}{|c|}{ Cumulative rainfall $(\mathrm{mm})$} & \multicolumn{2}{|c|}{ Rainy days (n) } \\
\hline & Control & 1-MCP & Control & 1-MCP \\
\hline 1 June to harvest & $0.04 \mathrm{NS}^{\mathrm{y}}$ & $0.02 \mathrm{NS}$ & $0.61 *$ & $0.68^{* *}$ \\
\hline 1 July to harvest & $0.12 \mathrm{NS}$ & $0.11 \mathrm{NS}$ & $0.62 *$ & $0.67 * *$ \\
\hline 1 Aug. to harvest & $0.51 *$ & $0.57^{*}$ & $0.72 * *$ & $0.74 * * *$ \\
\hline
\end{tabular}

${ }^{\mathrm{z}}$ Correlation analysis was performed for three different periods (1 June to harvest, 1 July to harvest, and 1 Aug. to harvest). Harvest dates ranged from 21 Sept. to 20 Oct. The severity of skin spot was quantified after 153 to $207 \mathrm{~d}$ of controlled atmosphere storage $\left(1.5\right.$ to $2.5{ }^{\circ} \mathrm{C}$, relative humidity greater than $92 \%, 2.6 \%$ $\mathrm{CO}_{2}$, and $2.0 \% \mathrm{O}_{2}$ followed by $14 \mathrm{~d}$ of cool storage). Severity of skin spot was scored on a 0 to 4 scale (where $0=$ no skin spot, through $4=$ more than half the surface area affected by skin spot; see text for further details). Fruit were treated with 1-methylcyclopropene (1-MCP) and untreated fruit served as controls (control).

${ }^{\mathrm{y}}$ Correlation coefficients followed by ***, **, *, or NS are significant at $P<0.001, P<0.01$, and $P<0.05$, or nonsignificant $(P>0.05)$, respectively.

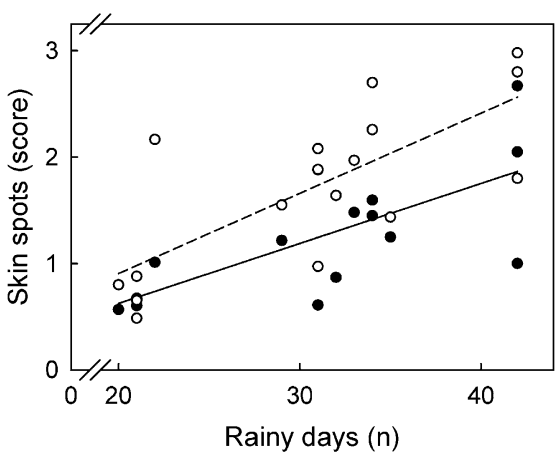

Fig. 1. Relationship between the severity of skin spot in 'Elstar' apples and the number of rainy days between 1 Aug. and harvest (range 21 Sept. to 20 Oct.) over nine seasons (2005-13). Fruit was treated with 630 ppm 1-methylcyclopropene (1-MCP, open symbols) or untreated (controls, closed symbols). The severity of skin spot was quantified after 153 to $207 \mathrm{~d}$ of controlled atmosphere (CA) storage $\left(1.5\right.$ to $2.5^{\circ} \mathrm{C}$, relative humidity greater than $92 \%, 2.6 \% \mathrm{CO}_{2}$, and $2.0 \% \mathrm{O}_{2}$ ) followed by $14 \mathrm{~d}$ of cool storage. Severity of skin spot was scored on a 0 to 4 scale (where $0=$ no skin spot, through $4=$ more than half the surface affected by skin spot; see text for further details). Regression equations were: control: skin spot (score) $=0.056( \pm$ $0.014) \times$ rainy days $(\mathrm{n})-0.505( \pm 0.453), r^{2}=$ $0.525^{* *} ; 1$-MCP: skin spot (score) $=0.075( \pm$ $0.018) \times$ rainy days $(\mathrm{n})-0.599( \pm 0.552), r^{2}=$ $0.552 * * *$.

for control fruit and after 34 rainy days for 1-MCP-treated fruit.

\section{Discussion}

Our results demonstrate that surface wetness results in the formation of microcracks in the cuticle, which in turn is a prerequisite for the formation of skin spot. This conclusion is based on the following observations. Surface wetness increased microcracking as indicated by both dye infiltration and the severity of skin spot (Table 1). The dye infiltration further demonstrates that microcracks, as often observed in scanning electron micrographs of apple fruit surfaces (Curry, 2008, 2009; Faust and Shear, 1972a, 1972b; Maguire, 1998; Maguire et al., 1999; Roy et al., 1999), are not completely sealed by wax deposition. Instead, microcracks causing skin spot in 'Elstar' traversed the cuticle resulting in desiccation and collapse of the underlying epidermal and hypodermal cells (Grimm et al., 2012). The subsequent browning of their protoplasts presumably results from phenol oxidation, making the skin spots easily detectable to the naked eye (Grimm et al., 2012). Interestingly, cuticular microcracking is also the first detectable symptom of russeting (Faust and Shear, 1972a). In fact, surface wetness during early development markedly increased russeting in this study (Table 2) and also in previous studies (Knoche et al., 2011; Wertheim, 1982). However, there was little evidence of skin spot formation from wetness treatment early in the season (Table 2). As the period of wetness was deferred to later in the season, the severity of russeting decreased steadily, whereas the severity of skin spot increased. When wetting occurred shortly before harvest (100 to 133 DAFB), surface wetness had essentially no effect on the severity of russeting, whereas that of skin spot remained at a high level (Table 2). These observations indicate that microcracking of the cuticle is critical in both russeting and skin spot. However, skin spot differs from russeting in that skin spot is induced by wetness later in the season, whereas russeting is induced by early-season wetness.

Interestingly, both russeting and skin spot may be viewed as natural repair processes whose effects are to restrict and limit the wound response to a small area of skin in the immediate vicinity of a cuticular microcrack. Anatomically, russeting represents the formation of a periderm, which differentiates in the subepidermal cell layers underlying a crack in the cuticle (Meyer, 1944). The phellem produced by the phellogen becomes visible when the fractured primary skin surface is shed and replaced. In skin spot, the damaged cells underlying a microcrack are sealed off by lignin impregnation of the cell walls (Grimm et al., 2012). Thus, russeting and skin spot are both natural repair processes, but one of these (russeting) is functional in young fruit, whereas the other (skin spot) is functional in older fruit.
Positive relationships between late-season surface wetness and skin spot severity were also obtained in the field observations. Here, the $r$ values were highest for correlations with late-season wetness. The higher $r$ values for relationships between the number of rainy days and skin spot severity are most likely because the number of rainy days more closely reflects surface wetness duration than cumulative rain fall. That 1-MCP increases the severity of skin spot is well established and is also consistent with earlier reports (Table 3; Fig. 1; Quast, 2004).

In conclusion, our results demonstrate that skin spot in 'Elstar' apple arises as a result of microcracking and that this is particularly a result of late-season surface wetness. In relation to the severity of skin spot, surface wetness is better described by the number (n) of rainy days than by the cumulative rainfall amount (mm). Based on the relationships we report here, a commercially critical skin spot score of 2 is predicted if there are more than 44 rainy days between 1 Aug. and harvest for control fruit and if there are more than 34 rainy days for 1-MCP-treated fruit.

\section{Literature Cited}

Curry, E.A. 2008. Effects of 1-MCP applied postharvest on epicuticular wax of apples (Malus domestica Borkh.) during storage. J. Sci. Food Agr. 88:996-1006.

Curry, E.A. 2009. Growth-induced microcracking and repair mechanism of fruit cuticles. Proc. SEM Annu. Conf., Soc. Expt. Mechanics, Albuquerque, NM. 23 Dec. 2013. <http:// sem-proceedings.com/09s/sem.org-SEM-2009Ann-Conf-s078p04-Growth-induced-MicrocrackingRepair-Mechanisms-Fruit-Cuticles.pdf $>$.

Faust, M. and C.B. Shear. 1972a. Russeting of apples, an interpretive review. HortScience 7:233-235.

Faust, M. and C.B. Shear. 1972b. Fine structure of the fruit surface of three apple cultivars. J. Amer. Soc. Hort. Sci. 97:351-355.

Grimm, E., B.P. Khanal, A. Winkler, M. Knoche, and D. Köpcke. 2012. Structural and physiological changes associated with the skin spot disorder in apple. Postharvest Biol. Technol. 64:111-118.

Hennecke, C., D. Köpcke, and W. Dierend. 2008. Dynamische Absenkung des Sauerstoffgehaltes bei der Lagerung von Äpfeln. Erwerbs-Obstbau 50:19-29.

Knoche, M. and E. Grimm. 2008. Surface moisture induces microcracks in the cuticle of 'Golden Delicious' apple. HortScience 43: 1929-1931.

Knoche, M., B.P. Khanal, and M. Stopar. 2011. Russeting and microcracking of 'Golden Delicious' apple fruit concomitantly decline due to gibberellin A4+7 application. J. Amer. Soc. Hort. Sci. 136:159-164.

Köpcke, D., R. Kirchhof, and P. Quast. 2002. Schalenflecken bei 'Elstar'. Mitteilungen des Obstbauversuchsringes des Alten Landes 57:272277.

Maguire, K.M. 1998. Factors affecting mass loss of apples. PhD thesis, Massey University, Palmerston North, New Zealand.

Maguire, K.M., A. Lang, N.H. Banks, A. Hall, D. Hopcroft, and R. Bennett. 1999. Relationship between water vapour permeance of apples 
and micro-cracking of the cuticle. Postharvest Biol. Technol. 17:89-96.

Meyer, A. 1944. A study of the skin structure of 'Golden Delicious' apples. Proc. Amer. Soc. Hort. Sci. 45:105-110.

Quast, P. 2004. Beispiele zum Wirkungspotenzial von 1-MCP bei der Reifehemmung verschiedener Apfelsorten unter verschiedenen
Lagerbedingungen. Mitteilungen des Obstbauversuchsringes des Alten Landes 59:329335.

Roy, S., W.S. Conway, A.E. Watada, C.E. Sams, E.F. Erbe, and W.P. Wergin. 1999. Changes in the ultrastructure of the epicuticular wax and postharvest calcium uptake in apples. HortScience 34:121-124.
Veltman, R.H., J.A. Verschoor, and J.H.R. van Dugteren. 2003. Dynamic control system (DCS) for apples (Malus domestica Borkh. cv. 'Elstar'): Optimal quality through storage based on product response. Postharvest Biol. Technol. 27:79-86.

Wertheim, S.J. 1982. Fruit russeting in apple as affected by various gibberellins. J. Hort. Sci. 57:283-288. 